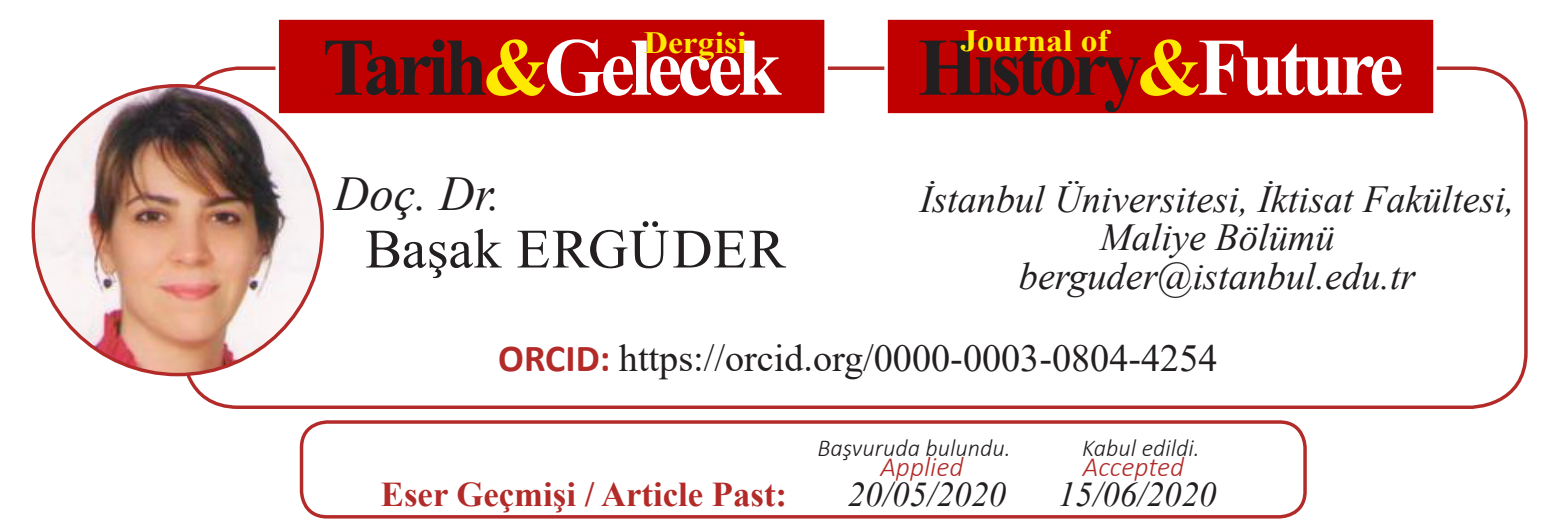

Araştırma Makalesi

DOI: http://dx.doi.org/10.21551/jhf.740349

Research Paper

Orjinal Makale / Orginal Paper

\title{
Düyun-u Umumiye İdaresi’nin Borç Yönetiminden Bir Kesit: İkramiyeli Tahviller
}

\author{
A Cut View Concerning the Debt Management of Ottoman Public \\ Debt Administration: Lots Turcs
}

$\ddot{O} z$

Buçalışmada uluslararası finans sermayenin Osmanlı ekonomisi üzerindeki etkilerinin Düyun-u Umumiye İdaresi'nin mali denetimi açısından analiz edilmesi amaçlanmaktadır. Osmanlı ekonomisi dünya ekonomisine tarımsal meta üretimi ihracatına dayalı diş ticaret ilişkileri ile entegre olmaktaydl. Osmanl ekonomisinde ticaret ve finans sermayesinin uluslararasılaşması, dış borçlanma ilişkilerinde rol oynayan kurumlar ile yüzyıl sonunda gerçekleşti. Osmanlı ekonomisinde kamu borçlarının mali denetiminde etkili olan Düyun-u Umumiye İdaresi, doğrudan yabancl yatırımları da desteklemekteydi. Yabanci demiryolu yatırımlarının risklerinin azaltılmasında rol oynayan Düyun-u Umumiye İdaresi, uluslararası sermaye yatırımları açısından güvenilir bir kurumdu. Çalışmada, Rumeli demiryolu yatırımının finansmanı için çıkarılan ikramiyeli tahvillerin incelenmesiyle, uluslararast sermayenin Osmanl ekonomisinde yarattı̆̆ finansallaşma ĕgilimi incelenmektedir. Çalışmada, Düyun-u Umumiye'nin mali denetim dışındaki faaliyetlerinin özellikle yabancı yatırımlara yönelik faaliyetlerinin sonuçlarını analiz edebilmek açısından Rumeli demiryollarının finansmanı için çıkarılan İkramiyeli tahviller incelenmektedir. 1870 ve 1872 yılında iki seri halinde çıkarılan ve kura ile ikramiye kazandıran tahvillerin getirisinden küçük yatırımcılar yararlanamamıştır.

Anahtar kelimeler: Osmanlı ekonomisi, Düyun-u Umumiye İdaresi, Birinci Küreselleşme Evresi, Dış Borçlar, İkramiyeli Tahviller.

ATIF: ERGÜDER Başak, "Düyun-u Umumiye İdaresi’nin Borç Yönetiminden Bir Kesit: İkramiyeli Tahviller", Tarih ve Gelecek Dergisi, 6/2 (Haziran 2020), s. (470-485) 


\section{Abstract}

In this study, it is aimed to analyze the effects of international finance capital on Ottoman economy in terms of the debt management of Ottoman Public Debt Administration. The integration of Ottoman economy with the world economy had been accelerated by international trade based on petty commodity production in agriculture. The internationalization of financial capital had been occurred with the help of the institutions that played a crucial role through debt management of Ottoman economy in the end of the century. Ottoman Public Debt Administration, the financial audit of public borrowing in the Ottoman economy, promoted foreign direct investments. The Ottoman Public Debt Administration that played a crucial role in decreasing the risks of foreign railway investments was a reliable institution for foreign investors. In the study, it is examined the financialization tendency created by international capital on Ottoman economy by analyzing the Lots Turcs that released to the market to finance Rumeli Railway investment to discuss the conclusions of activities directed to foreign capital of the Ottoman Public Debt Administration. Small investors had not been able to generate an income by drawing lots from Lots Turcs released to the market in two series in 1870 and in 1872.

Keywords: Ottoman economy, Ottoman Public Debt Administration, The First Era of Globalization, External Debts, Lots Turcs.

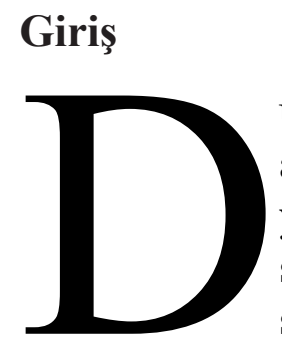

ünya ekonomisi açısından 19. yüzyılın büyüme yüzyılı olarak ele alınması, yüzyıl boyunca sanayi devriminin yarattığı yeni teknolojilere yatırım yapan toplumların kapsayıcı ekonomik kurumlara yönelmesinin sonucu olarak görülmektedir. ${ }^{1}$ Osmanlı ekonomisi yüzyılın özellikle son çeyreğinde, diş ticaret ilişkilerinin yarattığı ticarileşme ve parasallaşma eğilimleri ile birlikte büyümekteydi. Osmanlı ekonomisinde diş ticaret yoluyla gelen paranın dışa kapalı ekonomik yapıyı büyük ölçüde kırması, para arzına dayalı piyasa ekonomisi ile geleneksel üretim modeline dayalı içe kapalı ekonominin birlikte var olmasına zemin hazırlad1. Eldem'in verilerine dayanarak 1889-1911 döneminde Osmanlı ekonomisinde, 1873-1896 kriz dönemi hariç, GSMH'de yıllık ortalama artış yüzde 2'ydi. ${ }^{2}$ 500 yıllık dönem boyunca Osmanlı kentlerinin fiyat-ücret serilerindeki artış izlendiğinde 19. yüzyıl, Osmanlı ekonomisi açısından da büyüme yüzyılı olarak değerlendirilmektedir. ${ }^{3}$

Devletlerarası ticaret anlaşmalarıyla uluslararası ticaretin önündeki engeller kaldırılmasıyla Osmanlı ekonomisinin dünya kapitalizmine entegrasyonu, ticaretin finansmanı sorununu da beraberinde getirdi. Dönem boyunca etkili olan iktisadi kurumlar, kapitalist üretim ilişkilerinin ekonomide kurumsallaşmasında ticarileşme ve parasallaşma

1 Daron Acemoğlu ve James A. Robinson, Ulusların Düşüşü Güç, Zenginlik ve Yoksulluğun Kökenleri, çev. Faruk Rasim Velioğlu (İstanbul: Doğan Kitap,2018), 227.

2 Zafer Toprak, "From Liberalism to Solidarism: The Ottoman Economic Mind in the Age of the Nation State (1820-1920)" in Studies in Ottoman Social and Economic Life, ed. Raoul Motika, Christoph Herzog, Michael Ursinus (Heidelberg: Heidelberger Orientverlag, 1999), 178.

3 Şevket Pamuk, “Seçici Kurumsal Değişim ve Osmanlı’nın Uzun Ömürlülüğü”, Toplumsal Tarih 134, no.1 (Şubat 2005): 40. 
eğilimlerinin etkisini arttırdı. Yeni kapitalist üretim tarzıyla birlikte devam eden eski üretim yapısı modern ve geleneksel kurumlardan oluşan dual ekonomik yapıda devletin ekonomiye müdahalesini elzem kılmaktaydı. Osmanlı ekonomisinde iktisadi kurumlarının oluşumu ve işlevi, Avrupa ekonomilerinden farklı bir seyir izledi. Balta Limanı Ticaret Anlaşması (1838) Osmanlı'nın uluslararası ticarete açık bir pazar olmasında, Avrupa Kamu Hukuku'nun temel prensiplerini benimseyen Islahat Fermanı (1839) ise mülkiyet haklarının oluşmasında etkili olarak Osmanlı devletinin dünya ekonomisiyle entegrasyonunda önemli rol oynamıştır. ${ }^{4}$ Tanzimat dönemi (1826-1908) olarak adlandırılan iktisadi ve siyasi reformların yaşama geçirildiği kesitte gerçekleşen reformlar, Osmanlı ekonomisinde dışa açık liberal iktisat politikalarının hayata geçirilmesini yasal ve kurumsal olarak kolaylaştırdı. Tanzimat ve Islahat Fermanlarında yer alan vatandaşların eşitliği ilkesi, halkın devletle özdeşleşmesine ve yerel eşraf karşısında devletin halkın yanında yer almasına hukuki bir zemin hazırlamakla birlikte, Avrupa'nın Osmanlı'nın iç işlere karışmasını engellemeyi de hedeflemekteydi. Tanzimat dönemi, yerel eşraf üzerindeki denetimini arttıran bürokrasi ve merkezi yönetimin zenginleşmesiyle sonuçlanmıştır. ${ }^{5}$

Osmanlı ekonomisinde ticarileşme ve parasallaşma eğiliminin artması, kapitalizme geçiş sürecini de hılandırmaktaydı. Kapitalist ilişkilerin kurumsallaşmasından önce üretim düzeyi, sermaye birikimi ve teknolojik gelişme açısından Osmanlı ekonomisi durgun bir ekonomiydi. ${ }^{6}$ Küçük ölçekli tarımsal meta üretiminin uluslararası pazar ekonomisine açılması, kapitalist üretim ilişkilerinin tarımda yerleşik hale gelmesine neden oldu. Tarımsal üretimin ihracata yönelmesi ekonomiyi dışa açık bir pazar haline getirmekteydi. Osmanlı ekonomisinde merkezi otoritenin vergi olarak topladığı tarımsal artığının borçlanma ilişkileri sonucunda Avrupa ekonomisine ödenen finans sermayenin faiz gelirine dönüşmesiyle sermaye birikimi uluslararasılaşmaktayd.$^{7}$ Osmanlı ekonomisinde tarımsal meta üretimi fazlasının ihracatıyla artı-değer yaratılması ve artı-değerin yatırıma dönüştürülmesi yerine faiz giderlerinin ödenmesine kullanılması sözkonusuydu. Bu durum Osmanlı ekonomisinde sanayileşme yerine hızla parasallaşma ve ticarileşmeye dayalı bir finansallaşma eğiliminin oluşmasına katkıda bulunmaktaydı. Artı-değerin (sermayenin) gerçekleşmesinde uluslararası finans sermayenin egemenliğinde dış borçlanma ilişkileri rol oynamaktaydı. Tarımsal üretimin dış ticarete konu olduğu yüzyıl boyunca devlet bütçesi açık vermekte, vergi gelirleri artan kamu harcamalarını finanse etmekte yeterli olmamaktaydı.

Osmanlı ekonomisinde kamu borçlarının mali denetiminde olduğu kadar, yabancı demiryolu yatırımların risklerinin azaltılmasında da rol oynayan Düyun-u Umumiye İdaresi, uluslararası sermaye yatırımları açısından önemli bir kurumdu. Çalışmada, Rumeli demiryolu yatırımının finansmanı için çıarılan ikramiyeli tahvillerin incelenmesiyle, uluslararası sermayenin Osmanlı ekonomisinde yarattığı finansallaşma eğilimi ve Düyun-u Umumiye İdaresi'nin borç yönetiminin sonuçlarının analiz edilmesi hedeflenmektedir.

4 Gülten Kazgan, Tanzimat'tan 21. Yüzylla Türkiye Ekonomisi (İstanbul: İstanbul Bilgi Üniversitesi Yayınlar1, 2004), 21.

5 Metin Heper, Türkiye'de Devlet Geleneği (Ankara: Doğu Bat1, 1985),84-85.

6 Şevket Pamuk, Osmanl Ekonomisinde Bağımlılı ve Büyüme (İstanbul: Tarih Vakfı yayınları, 2005),11.

7 Çağlar Keyder, State and Class in Turkey: A Study in Capitalist Development (Newyork: Verso Books, 2003), 57. 


\section{Osmanlı Ekonomisinde Dış Borçlanma ve Düyun-u Umumiye İdaresi}

\subsection{Kurumsal Düzenlemeler ve Dış Borçlanma}

Osmanlı bütçesi 16. yüzyıldan itibaren sürekli açık vermekte ve bütçe açığı dolaşımdaki değerli madenden oluşan paranın vezin ve ayarıyla oynanarak elde edilen kısa vadeli ek gelirle kapatılmaktaydı. Tağşişler ile değeri düşürülen Osmanlı altın ve gümüş sikkesinin enflasyonist etki yaratmaması, narh uygulamasının fiyat hareketlerini sinırlamasından kaynaklanmaktayd1. ${ }^{8}$ Buna karşın 18. ve 19. yüzyıl boyunca artan askeri harcamalar ve vergilerin verimli biçimde tahsil edilememesi nedeniyle bütçe açığı sorunu yapısal hale getirmekteydi.18. yüzyıl boyunca Avrupa devletlerinin çoğunda vergi gelirlerinin artmasına karşın Osmanlı ekonomisinde vergi gelirlerinde kayıplar yaşanmakta, bütçe açıklarını finanse edecek yeni kurumların oluşmasına yönelik reformlar hızlanmaktaydı. 18. yüzyıl boyunca artan harcamalar ve maliyenin merkezileşmesi yönündeki reform çabalarının da sonuçsuz kalması sonucunda vergi gelirlerinde ciddi kayıplar yaşanmıştır. ${ }^{9}$ Tanzimat dönemi öncesi tarımsal üretim üzerinden elde edilen vergilerde kayıp yaşanmasında, mültezimlerin muaccele için borçlanması rol oynamaktayd. Tanzimat dönemi boyunca hayata geçirilen arazi reformları sonucunda vergi sisteminde yerel eşrafı güçlendirecek yetkiler daraltılmaktayd. Buna karşın vergi gelirinin tamamı hazineye girmemekteydi. Tanzimat Dönemi boyunca izlenen maliyeyi merkezileştirme politikası ile vergi gelirlerinin hazineye aktarılmasında yaşanan sorunlarının çözümü hedeflenmekteydi. Bütçe açığı sorununu çözmeye yönelik reformları gerçekleştirecek kesim Osmanlı bürokratlarıydı. Tanzimat dönemi boyunca bürokrasi, devlet gelirlerini arttırma gibi merkezi devletin güçlenmesini hedefleyen maliyeyi merkezileştirmeyi mümkün kılan reformlarla uyum içindeydi. ${ }^{10}$ Osmanlı İmparatorluğu'nda merkezi devletin güçlenmesi, geleneksel kurumlara yönelik yaklaşımda belirleyici olmakla beraber, bürokrasinin güçlenmesine de neden olmaktaydı.

Avrupa monarşilerini model alan merkezi bürokratik devlet anlayışını ve yeni ekonomik kurumları savunan bürokratlar ile Osmanlı geleneksel kurumlarını savunan toplumsal kesimler arasında dönem boyunca bir çatışma yaşanmaktayd1. ${ }^{11}$ Tanzimat döneminde özellikle devletin vergi sistemine yönelik reform arayışında modern ordu sistemine geçiş ve idari reformlarla artan kamu harcamaları önemli rol oynamaktaydı. Kurumsal değişimler, sadece devletin yeni gelir kaynakları oluşturma arayışının sonucu olarak değil aynı zamanda vergi tahsilatında yaşanan zorlukları aşacak yeni altyapı sistemleri oluşturma ve tarımsal üretime dayalı ekonomik yapının gelişimini sağlamanın da yolu olarak önemli rol oynamaktayd $1 .{ }^{12}$ Bütçe açıklarının kronikleşmesiyle süreleri uzatılan iltizam sözleşmeleri, iç borçlanma aracı olarak da kullanılmaktaydı. Ilttizam sisteminde

8 Zafer Toprak, “Küreselleşme Evreleri ve Türkiye’de Finansal Yapının Evrimi” Küreselleşen İstanbul'da Ekonomi içinde, ed. Çağlar Keyder (İstanbul: Osmanlı Bankası Arşiv ve Araştırma Merkezi,2010), 87.

9 K. Kıvanç Karaman and Şevket Pamuk, "Ottoman State Finances in European Perspective, 1500-1914”, The Journal of Economic History 70, No. 3 (September 2010): 622.

10 Heper, Türkiye'de Devlet Geleneği,79.

11 Halil İnalc1k, "Turkey Between Europe and the Middle East, Perceptions", Journal of International Affairs 3, no.1 (March-May, 1998): 8-9.

12 Karaman and Pamuk, “Ottoman State Finances”, 598. 
yapılan değişiklikler sonucunda verginin devlet memurları aracılığıyla toplanması, merkezi bürokrasinin güçlenmesini sağlamaktaydı.

Osmanlı ekonomisinde Tanzimat reformlarının yarattığı iktisadi dönüşüm, para politikalarının yeniden düzenlenmesi ile hayata geçirildi. 1850'li yıllarda para piyasasının yapılandırılmasına yönelik reformlar, kaimenin piyasaya sürülmesi, çift metalli para siStemine geçiş, modern bankaların kurulması ve dış borçlanmayla Avrupa ekonomisine entegrasyon hizlanmaktayd. ${ }^{13}$ Para piyasasına yönelik reformlar Osmanlı ekonomisinde tarımsal meta üretiminin ihracına dayalı yapının finansmanına yönelik olarak yeni yöntemlerin geliştirilmesini olanaklı kılmaktaydı. Kâğıt paranın basımı, üniter para sistemine geçiş, bankaların faaliyete geçmesi, Avrupa tarzı bütçeleme tekniklerinin kullanılması, dış borçlanmanın başlaması, yabancı ticaret odalarının merkezlerinin İstanbul'a taşınması gibi pek çok ekonomik gelişmenin yaşandığı 19. yüzyılının ikinci çeyreği, daha önceki yüzyıllarda pek de bilinmeyen bir iktisadi artı-değer yaratmaktayd $1 .{ }^{14}$ Osmanlı ekonomisinin dünya ekonomisine entegrasyonunda ticarileşme ve parasallaşma eğilimine uygun olarak gelişen borçlanma mekanizması, uluslararası sermayenin Osmanlı ekonomisinin mali denetiminde söz sahibi olmasına neden olmaktaydı. Birinci Küreselleşme Dönemi (18701914) boyunca uluslararası finans ağlarının uluslararası finans merkezlerini oluşturması, pek çok kenti finans ve ticaret merkezi olarak öne çıkarmaktaydı. Osmanlı ekonomisinde bu dönem yaşanan finansal gelişmeler, dönemin önemli bankerlerinin ve bankalarının İstanbul'a yerleşmesi, İstanbul'u uluslararası bir finans merkezi haline getirmekteydi.

Osmanlı ekonomisinde tarımsal üretime dayalı ihracat fazlası, dış borçlanma faaliyeti ile Avrupa finans sermayesinin faiz geliri olarak ödenmekteydi. Dış borçlanmanın başladığ 1 1854'ten, Osmanlı Bankası'nın kuruluşuna (1863), moratoryumun ilan edildiği 1875'den, Düyun-u Umumiye İdaresi'nin kurulmasına (1881) dek yaşanan gelişmelerin tümü parasallaşma ve ticarileşme sürecinin parçasıyd $1 .{ }^{15}$ Kırım Savaşı'nın ardından ilk dış borcun alımı, uluslararası finans çevrelerinin Osmanlı ekonomisine yönelik ilgisini arttırdı. Yüksek faizli yüklü miktarda borçlanmanın gerçekleştiği 1854-1876 dönemi boyunca Osmanlı devlet tahvilleri, Avrupa ekonomisinde sanayi üretimine talep yaratan bir mekanizma haline gelmekteydi. 1854-1875 yılları arasında toplam borçlanılan 5.297.676.500 Frank'ın, hazineye net gelir olarak giren miktarı 2.300.000.000 Frank'tır ve borçlanma faizleri yüzde 15-20 düzeyi gibi ortalamanın oldukça üstündedir. ${ }^{16}$

Osmanlı dış borçlanmasında en yüksek komisyon ve masrafla anılan borçlanmalar; Ağnam İstikrazı (1865), İkramiyeli Tahvil Borçlanması (1870) ile 1873 ve 1874 yılında gerçekleştirilen borçlanmalarıdır. Bu borçların ortak özelliği, borçlanma tutarı ile net elde edilen gelir arasındaki farkın oldukça yüksek olmasıdır. 1869-1875 yılları arasında Osmanlı tahvillerinin itibari değeri 5 kat artmasına karşın, Avrupa'da yaşanan mali kriz nedeniyle

13 Edhem Eldem, "Ottoman Financial Integration with Europe: Foreign Loans, the Ottoman Bank and the Ottoman Public Debt”, European Review 13, no.3 (July 2005): 434.

14 Pamuk, Osmanlı Ekonomisinde Bağımlılık ve Büyüme,160.

15 Toprak, "From Liberalism to Solidarism", 179.

16 Başak Ergüder, Galata Hanlart: Paranın Serüveni (İstanbul: SAV Yayınları,2011), 109. 
ortalama ihraç fiyatlarının en düşük olduğu borçlanmalar ise yine 1865,1870, 1873 ve 1874 borçlanmalarıdır. ${ }^{17} 1875$ Krizi Osmanlı dış borçlanmasında önemli bir kırılmaya neden oldu. 1874-75 bütçe genel gelirleri 22 milyon, diş borç ödemeleri 200 milyon, yıllık borç ödemeleri ise 12 milyon sterlin olmuştur. 1875 yılında Osmanlı hükümetinin borç ödemelerini durdurması ile birlikte, İstanbul hükümeti 1875-1880 yılları arasında borç faizlerinin yarısını nakit, diğer yarısını ise yüzde 5 faizli tahviller ile ödeme yolunu seçti. 1875 Ekim ayı boyunca çıkarılan kararname ve tebliğlerde borçların ödenmesi karşılı̆̆ında teminat olarak Misır vergisi, gümrük vergisi, tuz ve tütün gelirleri gibi önemli gelirler gösterildi. İki Kararname Arası Dönem olarak adlandıran 1875 Kararnamesi ile moratoryum ilan edilmesinden Düyun-u Umumiye İdaresi'nin kurulduğu Muharrem Kararnamesine (1881) kadar geçen dönem, Osmanlı dış borçlanması açısından yeni bir eşiğin açılması sözkonusuydu. İki Kararname Arası Dönemde çıkartılan kararnameler ve anlaşmalar ile alacaklı devletlere mali denetim hakkını tanıyan düzenlemelere gidilmekteydi. Hazineye kısa vadeli borçlanmanın sona ermesi ve mali denetimin uluslararası sermayenin temsil edildiği kurumlara devredilmesi ile dönemin sonunda gerçekleşti. ${ }^{18}$

Düyun-u Umumiye İdaresi’nce, Misır Vergisinin karşılık olarak gösterildiği 1854, 1855, 1871 ve 1877 borçları dişındaki tüm diş borçlar birleştirildi ve 1876-1881 yılları arasında birikmiş borçlar, Ramazan Tahvilleri adı altında toplam değeri yüzde 10 zamlı, ortalama ihraç değeri düşürülmüş tahviller olarak piyasaya sürüldü. Şirketlerin satın aldıkları yeni tahvillerin piyasada halka düşük fiyatlarla satılması, hızla gelir elde edilmesini kolaylaştırmaktaydı. Rumeli Demiryolları için çıkartılan ikramiyeli tahviller, Düyun-u Umumiye İdaresi tarafından yüzde 10 zamlı fiyatlarla piyasaya sürüldü. ${ }^{19}$ Düyun-u Umumiye İdaresi, tahvil sahiplerine ayrılmış olan gelir kaynaklarından elde edilen geliri yönetme, toplama ve saklama yetkisine sahipti. Muharrem Kararnamesi’ne göre Osmanlı İmparatorluğu'ndaki gelir kaynaklarından elde edilen toplam gelirin beşte dördü borç faizi ödemelerine, kalan gelir ise borçların miktarının azaltılmasına harcanacaktı. Bu düzenlemeden Osmanlı ekonomisinden çok Osmanlı tahvillerini elinde tutan uluslararası kreditörler, gelir kaynaklarının karlılığını arttırarak yararlanacaklardır. ${ }^{20}$

21 maddeden oluşan Muharrem Kararnamesi'nde yer alan maddelerin ilk kısmı iç ve diş borçların konsolidasyonuna yönelik olup, ikinci kısımda konsolide edilen borçlara yönelik düzenlemeler yer almaktadır. Kararname'nin son maddelerinde Düyun-u Umumiye İdaresi'nin kuruluşu ve Babıâli ile ilişkileri düzenlenmekteydi. Muharrem Kararnamesi ile diş borçlar Avrupa tahvil piyasasında değeri düşük yeni tahviller ile değiştirilerek borç miktarı yüzde 56 oranında azaltıldı. Borç tahvilleri ödeme planına bağlanarak güven derecesine göre 4 gruba ayrıldı. Buna göre A Serisi borçlar 1858 ve 1862 borçlanmaları, B Serisi borçlar 1860,1863,1864,1874 borçları, C Serisi borçlar 1865,1873 borçları ve D Serisi borçlar Düyun-u Umumiye tahvilleri ile ikramiyeli tahvillerdi. 30 Nisan 1890 sözleşmesi

17 Biltekin Özdemir, Osmanlı Devleti Dış Borçları (Ankara: Maliye Bakanlığı Strateji Geliştirme Başkanlığ 1,2010$), 96$.

18 Şevket Pamuk, Osmanlı Imparatorluğu’nda Paranın Tarihi (İstanbul: Tarih Vakfı Yurt Yayınları, 1999).

19 İ. HakkıYeniay, Yeni Osmanlı Borçları Tarihi (İstanbul: Ekin Yayınevi, 1964), 66.

20 Giampolo Conte and Gaetano Sabatini, "The Ottoman External Debt and its Features under European Financial Control (1881-1914)", Journal of European Economic History 43, no.3 (2014): 82. 
ile B, C ve D Serisi (ikramiyeli tahviller olarak bilinen demiryolu hisselerini de içeren) borç serileri birleștirilerek, faiz oranları yüzde 5'ten yüzde 4'e indirildi. Son derece tartışmalı olan bu yeni sözleşme, büyük tahvil sahiplerinin protestoları ile karşılandı 1890 Sözleşmesi, Düyun-u Umumiye İdaresi'nin çalışma faaliyetlerine gelecek iki yıl boyunca hâkim olacak çelişkilere yol açacaktı. Sözleşmeye göre tahvil serilerinin birleştirilmesi sonucunda tahvillerin toplam nominal değeri 83,910,441 TL idi. Anlaşmada yeniden yapılanma süreci ve hesapların ayrıntılı olarak aktarıldığı maddelerin yanısıra yapılan işlemlerin avantaj ve dezavantajlarının tartışıldığı bir açıklamaya yer verilmekteydi. Buna göre birleştirilen tahvil serilerinin amortismanı 1943-44 mali y1lına kadar uzatılmaktayd. ${ }^{21}$

Borç tahvillerinin riski 1882-1901 yılları arasında azalmış ve düşük faiz oranlarıyla borçlanılmıştı. Düyun-u Umumiye İdaresi, 1903 yılında Osmanlı borçlanmasında değiştirme ve birleştirme işlemi yapmasının ardından, demiryolu yatırımlarının vergi gelirinde yarattığ artışın gelirini de bütçesine ekleyerek en verimli dönemini 1903-1914 yılları arasında yaşadı. Osmanlı hükümeti, demiryolu imtiyazlarını alan kişi ve kurumlara yapılan ve işletilen her kilometre demiryolu için yıllık 150 bin Frank gayrisafi kâr garantisi vermekte, işletme gelirleri bu miktardan az olduğu durumda her kilometre demiryolu için yıllık 15 bin Frank gayrisafi geliri sağlamak amacıyla Düyun-u Umumiye İdaresi Aşar vergisinin toplanmasını yönetmekteydi. Demiryolu hattının geçtiği İzmit, Ertuğrul, Kütahya ve Ankara sancaklarında Aşar açık artırmaya çıkarıldığı zaman Düyun-u Umumiye İdare'sinin görevlisi hazır bulunacak ve açık arttırmayı kazanan mültezimlerin daha önce hükümete vermek zorunda olduğu senetler, sancaklardaki Düyun-u Umumiye görevlilerine verilecek ve karşılıkları da ancak görevlilere ödenecekti. ${ }^{22}$ Düyun-u Umumiye İdaresi, demiryolu altyapısına sahip olan yeni bölge sayısının artmasını sağlayarak, kendisine bırakılacak yeni gelir kaynaklarına sahip olmak istemekte ve demiryolu imtiyazlarını doğrudan desteklemekteydi. Borçların birleştirilmesi ile yeni tahviller çıkarılması ise artan tahvil fiyatları nedeniyle bu dönem kurumun gelir kaynaklarını güçlendirdi. 1886-1914 döneminde ortalama yüzde 4 faiz ve yüzde 85 ihraç fiyatıyla toplam 150 milyon sterlin yeni dış borçlanmanın gerçekleşmesi kurumun başarısı olarak görülmektedir. ${ }^{23}$ Birinci Dünya Savaşı boyunca dış borç ödemelerinin askıya alınmasına karşın Düyun-u Umumiye İdaresi diğer faaliyetlerine devam etmekteydi. 1915 yılında Osmanlı ekonomisine kâğıt para basması için iki kez başvurulan Düyun-u Umumiye İdaresi, altın karşılığı olan kâğıt para emisyonunu kabul ederek, Osmanlı Bankası'nın emisyon bankası olma işlevini üstlendi ve Berlin ile Viyana'dan toplam 150 milyon Frank borç alınarak finanse edilen emisyonlarda bulundu. ${ }^{24}$ Birinci Dünya Savaşı boyunca Alman hazine bonoları ile finansman açı̆̆ını kapatan hükümet, Düyun-u Umumiye İdaresi tarafından yapılan ilki Avusturya ve Alman hükümetlerinden altın karşılığı diğeri Alman hazine bonosu karşılığı olan yedi tertip evrak-1

21 Alexander Johnson, The Gabriel Aubaret Archive of Ottoman Economic and Transportation History (Dasa Pahor), 18, http://www.pahor.de (January 29, 2019), s.82

22 Donald C. Blaisdell, Osmanlı Imparatorluğu’nda Avrupa Mali Denetimi: Düyunuumumiye, çev. Ali İhsan Dalgıç (İstanbul: Doğu-Batı yayınları, 1979), 120.

23 Eldem, "Ottoman Financial Integration”, 442.

24 Zafer Toprak, "Osmanlı Devleti’nin Birinci Dünya Savaşı Finansmanı ve Para Politikası”, ODTÜ Gelişme Dergisi (Özel Sayı 1979-1980): 215. 
nakdiye basımı karşılığında yaklaşık 161 milyon liralık emisyon gerçekleştirilmiş̧tir. ${ }^{25}$ Birinci Dünya Savaşı dönemi boyunca kurum, 1915 öncesinde müttefik olan devlet vatandaşlarının borçlarını ödemiştir. 1918 yılında ise Trablus tazminatı olarak 700 bin Osmanlı lirası birleştirilmiş borcu ödemiştir. ${ }^{26}$

\subsection{Düyun-u Umumiye İdaresi’nin Gelir Kaynakları ve Organizasyon Yapısı}

Muharrem Kararnamesi (1881) ile kurulan Düyun-u Umumiye İdaresi, yabanc1 yat1rımcılar açısından işbirliği yapılacak güvenilir bir temsilciydi. ${ }^{27}$ Düyun-u Umumiye İdaresi borçların yönetiminde Avrupa sermayesini etkin kılmaktaydı. Avrupa finans sermayesi için garantör olan kurum Osmanlı ekonomisinde Avrupa mali denetim mekanizmasını oluşturmaktayd. Muharrem Kararnamesi'nin 21. maddesinde diplomatik ve politik müdahale seçeneğinin ortaya konulması, kurumun özel nitelikli mali denetim özelliğini muğlaklaştırmakta ve devletlerin doğrudan denetimine kapıyı aralamaktaydı. Borç servisi için daha önce Rüsum-u Sitte İdaresi'ne bırakılan dolaylı vergilerle birlikte pek çok önemli devlet gelirinin toplanmas1, yönetilmesi ve borçlanmaya ayrılması yetkisi Düyun-u Umumiye İdaresi'ne verilmiş, bütçe gelirlerinin yaklaşık beşte biri borç ödemesi tamamlanana kadar kuruma bırakılmıştı. ${ }^{28}$ Düyun-u Umumiye İdaresi, y1lsonunda Osmanlı bütçesi ile birleştirilip aynı tür hesap kontrolüne tabi tutulan bütçesi nedeniyle değil, yönettiği gelir kaynakları ve yabancıların çoğunluğa sahip oldukları yönetim kurulu nedeniyle devlet içinde devlet olarak görülmekteydi. ${ }^{29}$

Düyun-u Umumiye Konseyi'nin gelir kaynakları içinde yer alan ve 1862'de hükümet tarafından kurulan Tuz Tekeli, aynı yıl yapılan borçlanma için gelirleri bakımından güvence sunmaktaydı. İstanbul, Edirne, Bursa ve Samsun çevresindeki bazı bölgelerin ipek aşarı gelirleri Konsey'e aitti. Konseyin kullanımına bırakılan diğer dolaylı vergiler, pul resmi, balık vergisi ve alkol vergisiydi. İpek aşarı geliri alınan tedbirler sonunda artan ipek üretimi sonunda ciddi bir gelir kaynağ 1 haline gelmişti. 1880'de ipek üretimi 200.000 liradan, 1910'larda 2.8 milyon liraya yükselirken, ipek aşarı geliri de 20.000'den 200.000 altın liraya yükseldi. ${ }^{30}$ Düyun-u Umumiye İdaresi, ispirto ve ispirtolu içkilerden alınan yüzde 15 oranındaki muamele vergisini yüzde 8 oranındaki gümrük vergisi seviyesine indirmek için girişimlerde bulunmuştu. Üzerindeki vergi yükü azaltılan ispirto ve ispirtolu içkilerden elde edilen gelirde yüzde $38^{\prime}$ lik bir artış kaydedildi. ${ }^{31}$

Muharrem Kararnamesi'nin 7. maddesi uyarınca gümrük gelirinin hazineye ayrılan payının üzerine çıkan miktarın Düyun-u Umumiye İdaresi'ne bırakılması ve bu gelirin İdare tarafından yönetilmesi, kuruma yaptırım gücü sağlamaktaydı. Avrupa ile dış ticarette,

\footnotetext{
25 Toprak, “Osmanlı Devleti’nin Birinci Dünya Savaşı Finansmanı”, 217.

26 Blaisdell, Osmanlı Imparatorluğu'nda Avrupa Mali Denetimi, 173.

27 Blaisdell, Osmanlı Imparatorluğu'nda Avrupa Mali Denetimi, 98.

28 Eldem, “Ottoman Financial Integration”, 442.

29 Bedri Gürsoy, "100. Y1lında Düyun-u Umumiye İdaresi Üzerinde Bir Değerlendirme”, İstanbul Üniversitesi Iktisat Fakültesi Mecmuası 1-4 (Şükrü Baban'a Armă̆an), cilt:40, (1984): 21.

30 Gürsoy, "100. Yilında”, 41.

31 Gürsoy, "100. Yilında",42.
} 
gümrük vergisinin kurum tarafindan toplanması, Düyun-u Umumiye İdaresi'ni Avrupa devletlerinin vekili haline getirmekteydi. Osmanlı Hükümeti yeni borçlanmalar için gümrük vergileriyle yeterli geliri elde etmeyi hedeflerken kurum, Osmanlı ekonomisine yatırım yapacak olan Avrupa sermayesinin çıkarlarını da güvence altına almaktaydı. ${ }^{32}$ 1907-1915 yılları boyunca gümrük vergisi Düyun-u Umumiye İdaresi tarafından topland1. 25 Nisan 1907 'de imzalanan Ticaret Anlaşması ile ithal edilen mallara yüzde 8 vergi konulurken, hedeflenen gümrük vergisinin yüzde 11'e çıkarılmasıydı. Gümrük vergisi gelirinin yüzde 75 'i hazineye aktarılırken, yüzde 3 ek vergi Düyun-u Umumiye İdaresi tarafından toplanarak il gümrük veznelerine yatırıldı. Hükümet tarafından Makedonya illerine (Kosova, Selanik ve Manastır'a) ayrılan bu gelirin 250.000 Osmanlı lirasını geçen kısmı borçlanmayı finanse etmek üzere Düyun-u Umumiye İdaresi tarafından yönetilecekti. 1907 Ticaret Anlaşması ile Düyun-u Umumiye İdaresi'nin yetkileri genişlemekte ve kurum gümrük rejimi üzerinde yaptırım gücüne sahip olmaktaydı. 1916 yılında değer esaslı matraha geçişle birlikte gümrük vergisi gelirlerinin yarısı İdare'ye bırakılmıștı. Gümrük vergisi oranları ise 1907'den 1914'e artış kaydederek, yüzde 15 düzeyine yükselmişti. ${ }^{33}$

Düyun-u Umumiye İdaresi'nin gelir kaynakları arasında Tuz Tekeli ve Tütün Rejisi de önemli bir paya sahipti. Tuz Tekeli'nden elde edilen gelirler 1914 yılında 1 milyon 103 bin 23 liraya yükselerek, İdare yönetiminde elde edilen gelir yüzde 26'ya varan oranda bir artış göstermekteydi. ${ }^{34}$ Alacaklı ülkelerin kurduğu ve gelirleri Osmanlı dış borçlarını ödemek için kullanıldıktan sonra kalanı Düyun-u Umumiye İdaresi'ne devredilen Tütün Rejisi, Osmanlı ekonomisinin en önemli gelir kaynağı olan tütün, tuz ve alkolden toplanan vergilere 40 y1l boyunca sahip oldu. Reji'de Avusturya, Almanya, İngiltere ve Osmanl1 Hükümeti'ni temsil eden üyelerin yanı sıra Fransız sermayesini temsil etme gücüne sahip olan Osmanlı Bankası da yer almaktaydı. ${ }^{35}$ Tütün Rejisi, Osmanlı ekonomisinde doğrudan yabancı yatırımların ortalama yüzde 23'ü değerindeydi ve Dünya ekonomisindeki en büyük tütün iştirakiydi. ${ }^{36} 1884$ yılında Viyana, Berlin ve Osmanlı Bankası aracılığıyla Parisli sermayedarların katıldıkları ortak iştirak, Osmanlı Tütünleri İşletme Ortaklığı olarak tütün ve sigara üretimini devrald.$^{37}$ Düyun-u Umumiye İdaresi, şirket ortaklarına yüzde 8 'lik bir kâr garantisi verdikten sonra kalan geliri Osmanlı hazinesi ile paylaşmaktaydı. Tütün tekeli Osmanlı Bankası'nın da denetiminde olan bir kuruluş olarak Düyun-u Umumiye İdaresi'nin en önemli gelir kaynaklarından biriydi. ${ }^{38}$

Düyun-u Umumiye İdaresi yönettiği gelir kaynakları ile ekonomi üzerindeki müdahale gücünün arttırmaktaydı. Bununla birlikte kurum Osmanlı bütçesinde gittikçe büyüyen bir gelir kaynağına sahipti. Osmanlı dış borçlarını denetleyen ve yöneten Düyun-u Umumiye İdaresi, Muharrem Kararnamesi'nin ilgili maddelerine uygun olarak Osmanlı

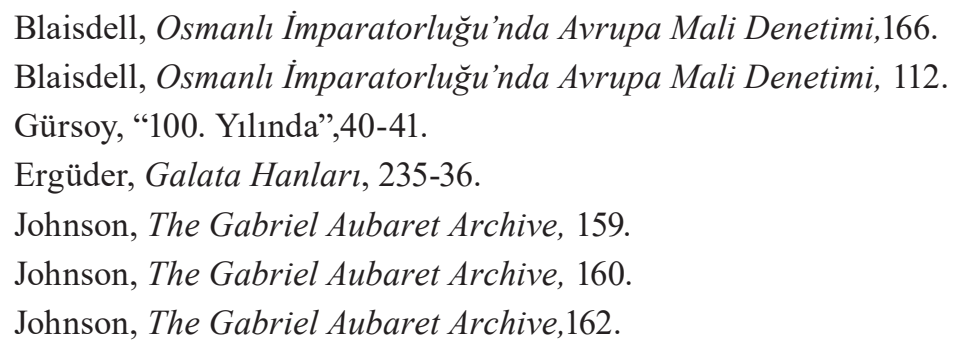


tahvil alacaklılarının borçlarının geri ödenmesini garanti altına alma hedefine uygun olarak faaliyette bulunmaktaydı.

Düyun-u Umumiye İdaresi, organizasyonu ve işleyişi açısından Avrupalı devletlerin himayesinde olan bir kurumdu. ${ }^{39}$ Düyun-u Umumiye İdaresi üyeleri, devletlerin resmi olmayan onayı ile atanmakta ve resmi hükümethizmetlerinde bulunduktan sonra devletlerinin resmi görüşüne sahip olarak konseye geçmekteydi. Üyeler arasında, Osmanlı ekonomisine yatırım yapan demiryolu ortaklıklarının yönetim kurulu üyeleri de yer almaktaydı. Düyun-u Umumiye İdaresi, uluslararası sermayenin Osmanlı ekonomisi üzerindeki etkinliğini sadece borçlanma ilişkileri ile arttırmamış, aynı zamanda yabancı firmaların altyapı sektörüne yönelik yatırımlarında kârlılıklarını temin edici uygulamalarla mali ve iktisadi sistemde tam ve tek taraflı bir denetim kurmuştur. ${ }^{40}$ Osmanlı ekonomisinde uluslararası sermayenin mali sistemde tek taraflı denetim kurmasına imkân sağlayan tarihsel gelişmeler, Osmanlı ekonomisinin dünya kapitalist sistemine entegrasyonunu hızlandırmaktaydı. Osmanlı ekonomisinde Düyun-u Umumiye İdaresi'nin diş borçlanma ile birlikte yürüttügü demiryolu yatırımları yabancı yatırımcıların kârlarını garanti altına alan borçlanma serileri ile birlikte yürütülmekteydi. Rumeli Demiryolu yatırımının finansmanı için çıkartılan ikramiyeli tahviller bu yönde yürütülen ilk faaliyetlerdi. Düyun-u Umumiye İdaresi tarımsal meta üretimi ihracatına dayalı Osmanlı ekonomisinde, demiryolu yatırımlarını desteklemiş ve 1890’lı yıllar boyunca yabancı yatırımcılara yönelik faaliyetlerini sürdürmüştür.

\section{Rumeli Demiryolu Yatırımının Finansmanında İkramiyeli Tahviller}

Osmanlı ekonomisinin uluslararasılaşma düzeyini belirleyen üretim tarzı, emek sömürü oranı yüksek olan sektörlerde doğrudan yabancı yatırımlarla desteklenmekteydi. Yabancı devletler tarafından yapılan demiryollarına hükümetin verdiği kilometre garantisi hazineye oldukça ağır bir yük getirmekle birlikte, demiryolları sayesinde vergi gelirlerinde muazzam bir artış yakalanmıştı. Demiryolu hatlarının geçtiği güzergahlardaki Aşar vergisi Düyun-u Umumiye görevlileri tarafından toplanmakta ve mültezimlere ödenecek miktarın dışında kalan meblağ hazineye kalacağı için Düyun-u Umumiye İdaresi Aşar vergisini kayıpsız olarak toplamayı hedeflemekteydi. Düyun-u Umumiye İdaresi yönetiminde Aşar vergisinin toplandığı bölgelerde vergi gelirlerinde önemli bir artış yakalanmış, 1889-1914 yılları arasında Anadolu demiryolu hattının geçtiği bölgelerden toplanan vergi geliri 254.51 milyon Osmanlı lirası, devletin bu şirkete kilometre güvencesi olarak ödediği miktar ise yaklaşık olarak 60.16 milyon Osmanlı lirasına ulaşmıştı. ${ }^{41}$ Demiryolu imtiyazlarına 18881907 yılları Düyun-u Umumiye İdaresi aracılık etmekteydi. Yabancı yatırımcılar için de oldukça etkin bir yatırım alanı olan demiryolları Düyun-u Umumiye İdaresi'nin korumasında düşük riskli ve oldukça yüksek getirili bir yatırım alanıydı. ${ }^{42}$ Demiryolu yatırımları ile Osmanlı vilayetleri Dünya ekonomisine entegre olurken, Düyun-u Umumiye İdaresi'nin iş

\footnotetext{
39 Blaisdell, Osmanlı Imparatorluğu’nda Avrupa Mali Denetimi, 99.

40 Eldem, “Ottoman Financial Integration”, 443.

41 Murat Birdal, The Political Economy The Political Economy of Ottoman Public Debt Insolvency and European Financial Control in the Late Nineteenth Century (Newyork: Tauris Academic, 2010), 2.
}

42 Birdal, The Political Economy, 100. 
birliğiyle Avrupalı sermayedarlar kârlı bir yatırım alanı olan demiryolu inşasını güvenlik içinde gerçekleştirebilmekteydiler.

Demiryolu imtiyazları, hükümet, girişimciler ve tahvil sahiplerinin çıkarlarını gözeten bir yatırım alanı haline gelmekteydi. Demiryolu ortakları ile Düyun-u Umumiye İdaresi arasındaki işbirliği tahvil sahiplerinin çıkarları ile de uyumluydu. Hükümet açısından vergi gelirlerini toplamanın yanısıra ticaret ve savunma ile ilgili çıkarların korunması anlamına gelen bu işbirliği girişimcilerin kârlarının artmasına, tahvil sahiplerinin ise devlet gelirinin artması ile Osmanlı borçlarının ödenmesine yönelik beklentilerin gerçekleşmesini de sağlamaktaydı. Bu noktada, 1870 ve 1872 yıllarında ihraç edilen ikramiyeli tahviller, demiryolu yatırımlarının finansmanında Osmanlı tahvillerinin ihracı bakımından önemli bir örnek teşkil etmektedir.

İstanbul'u Avrupa'ya ve Tuna boylarına bağlayacak 2500 km.' lik Rumeli Demiryolları projesi 1869 yılında, banker müteahhit Baron Hirsh'e verildi. Biri yapım diğeri işletme şirketi olmak üzere projenin yapımı için iki ayrı şirket kuruldu. ${ }^{43}$ Yapım şirketinin inşaatın gerçekleştirilmesi için kaynak ihtiyacına yönelik olarak 1870 y1lında 400 Frank nominal değeri olan 792 milyon Frank tutarında 1.980.000 adet tahvil ihraç edildi. Tahvillerin faiz oranı yüzde 3 ve geri ödeme süresi 1975 yılıydı. Borcun amortismanı 105 yıl gibi geniş bir zaman dilimine yayılmaktaydı. Baron Hirsh tarafından yüzde 3 faiz oranlı 128,5 Frank'a alınan tahviller, 150 Frank'a Avrupalı tahvil alacaklılarına satıldı. İkramiyeli tahviller pek çok farklı Avrupa kentinin borsalarında işlem görmeye başladı. Londra, Paris, Berlin gibi uluslararası finans merkezlerinde satışa sunulan tahviller, Rumeli demiryollarının finansmanı için önemli bir fon oluşturmaktaydı. ${ }^{44}$

İkramiyeli tahvillerin amortismanında izlenen yol ise diğer borçlanmalardan oldukça farklıydı. İlk yönteme göre normal amortisman planına göre yapılacak ödeme planında faiz ödemesi yapılmayacak, sadece anapara ödemesi nominal değer üzerinden yapılacaktı. Diğer yöntemde ise tahviller için kura çekimi yapılacaktı. İki ayda bir çekilecek kuralarda en yüksek ikramiyeli ilk grup tahvile 600.000, ikinci gruba 300.000 Frank ikramiye isabet edecek ve yılda 100 tahvil ikramiyeli olarak ödenecekti. ${ }^{45}$ Tahviller için en düşük ikramiye 28.000 Frank, en yüksek ikramiye ise 600.000 Frank olacak ve çekilen kurada amortisman hakkı kazananlar için bir de sermaye kazancı oluşacaktı. 58 Frank'a ihraç edilen tahviller 400 Frank nominal değere sahip oldukları için ödemelerin devam ettiği 1875 yılına kadar tahvil sahipleri nominal değer ile satın aldıkları değer arasındaki fark kadar sermaye kazancı sağlamaktayd..$^{46}$

Osmanlı borç faiz ve anapara ödemelerinin 1875 yılında çıkartılan kararname ile durdurulması, ikramiyeli tahvillerin anapara ve faiz ödemelerini de 1881 yılına

43 İlhan Tekeli ve Selim İlkin, Cumhuriyetin Harcı: Modernitenin Altyapısı Oluşurken (İstanbul: İstanbul Bilgi Üniversitesi Yayınlar1, 2004), 162.

44 Zafer Toprak, "Osmanlı İkramiyeli Devlet Borçları, Rumeli Demiryolları ve Duyunu Umumiye”, Toplum ve Bilim Dergisi (Güz 81- Kış 82, 1981): 117.

45 Toprak, "Osmanlı İkramiyeli Devlet Borçları”, 117-118.

46 Toprak, "Osmanlı İkramiyeli Devlet Borçları”, 118. 
kadar durdurdu. Düyun-u Umumiye İdaresi Osmanlı tahvil borçlarını ödemek için gelir kaynaklarından kotalar ayırmıştı. Kotanın $1 / 5^{\prime} \mathrm{i}$ borçlarının anaparalarına, $4 / 5$ ' $\mathrm{i}$ ise faiz ödemelerine ayrılmıştı. İkramiye tahviller için ise faiz ve anapara ödemesi için kota ayrılmamış, diğer borçların amortismanı belirli bir rakama ulaşıncaya kadar ikramiyeli tahvillere faiz ödenmemesi kararlaştırılmıştı. ${ }^{47}$ İkramiyeli tahvil sahiplerinin elde edeceği gelir, tahvillerinin piyasa değeri ile nominal değeri arasında oluşacak farktan ibaretti. İkramiyeli tahvillerin alacaklıları açısından oldukça aleyhte olan bu durumu daha da ağırlaştıran şartlar, Muharrem Kararnamesi'nin borçların idaresi ile ilgili 12. maddesinin farklı yorumlanmasından kaynaklanmaktaydı. İlgili madde "her sene hâmillere muhassas varidat safi hasılatın 1/5'i evvelce itfa edilmiş olan tahvilatın faizleri de buna ilave edilmek suretiyle amortismana tahsis olunur"48 ifadesi ile düzenlenmişti. Ayrılan 1/5 oranından tüm tahviller eşit derecede istifade etmemekle birlikte, D Serisi borçlar arasında yer alan ikramiyeli tahviller borç amortismanı açısından öncelikli olan tahviller arasında yer almamaktaydı. İkramiyeli tahviller için Düyun-u Umumiye İdaresi'nin yıllık gelirinin yüzde13,46'sı borç geri ödemesine ayrılmışken, bu oranın sadece 4/5'i kullanılmış, kalan $1 / 5^{\prime} \mathrm{i}$ ise diğer borçların geri ödenmesine tahsis edilmişti.

İkramiyeli tahvillerin ödenmesi konusunda hazırlanan ilk 14 aylık ödeme planına göre Düyun-u Umumiye İdaresi son beş yılda ikramiye kazanan tahviller için yüzde 20 tazminat ödemesi yapmayı kararlaştırmış, aynı yıl çıkarılan tahvillerin nominal değerinin yüzde 58'ini ödemeyi, yani 400 Frank değerindeki tahviller için 232 Frank ödemeyi hedeflemişti. ${ }^{49}$ Buna karşın 1890 yılında Osmanlı borçlarının birleştirilmesi ve konversiyonunda ikramiyeli tahviller dışarıda tutuldu. Borçların konversiyonuyla sağlanan yıllık tasarruf miktarından, D Serisinde yer alan ikramiyeli tahvil borçlarının ödenmesi için pay ayrılmadı. Düyun-u Umumiye İdaresi'nin tahvilat gelir fazlasının bir kısmı ile aynı tahvilleri satın alarak oluşturacağı portföy tahvil komitelerinin ortak itirazları ile karşıland $1 .{ }^{50}$ Hükümet ve Düyun-u Umumiye İdaresi'nin lehine olan bu durumun tahvil alacaklılarının gelir kaybına yol açacağı düşüncesiyle açılan davaların ardından 1893 yılında Avusturya-Macaristan Komitesi ile Osmanlı Maliye Nezareti'nin talebiyle yapılan görüşmenin sonucunda bir borç ödeme planı hazırlandı. Hazırlanan ödeme planına göre, ikramiyeli tahvillerin itfa oran1, nominal değerin yüzde 58'i yerine yüzde 75 'inden yapılacaktı. ${ }^{51}$ Ödeme planının uygulanması hem hükümet hem de tahvil sahipleri lehine bir durum yaratmaktaydı. Borcun itfasının tamamının gerçekleştirilmesi, ikramiyeli tahvillerin ödenmesi için ayrılan gelir kaynaklarının diğer borçlara tahsis edilmesini sağlayarak, Düyun-u Umumiye İdaresi ve hükümetin toplam borç faiz yükünü azaltacaktı. İkramiye için kura çekerek gerçekleştirilecek itfa, daha fazla sayıda ikramiyeli tahvil borcunun geri ödenmesi sonucunda tahvil sahiplerinin çıkarına uygun olacaktı. ${ }^{52}$ Diğer yandan itfa oranlarının arttırılması ile yapılacak fazla ödemenin yerine hükümet tarafından tahvillerin

47 Toprak, "Osmanlı İkramiyeli Devlet Borçları”, 119.

48 Charles Morawitz, Türkiye Maliyesi (Ankara: Maliye Bakanlığı Tetkik Kurulu Yayını,1978), 204.

49 Toprak, “Osmanlı İkramiyeli Devlet Borçları",119.

50 Toprak, “Osmanlı İkramiyeli Devlet Borçları”,120.

51 Morawitz, Türkiye Maliyesi, 207.

52 Morawitz, Türkiye Maliyesi,208. 
piyasadan satın alınması daha makul görülmekteydi.

Hükümet açısından tahvillerin itfa oranının yükseltilmesi konusunda en önemli endişe, Düyun-u Umumiye İdaresi üyelerinin dışarıya bilgi sızdırarak, Avrupalı bankerlerle birlikte tahviller üzerinden spekülatif bir gelir elde etmeleriydi. ${ }^{53} 1893$ yılında hazırlanan borç ödeme planı uygulanmadı. Bu planın uygulanmaması ikramiyeli tahvillerin daha çok spekülasyonlarla anılmasına yol açmaktaydı. Osmanlı toplumunda borsada havaoyunları ile önemli kârlar elde eden kesimlerin yanısıra tahvillerine ikramiye çıkan ve tahvil gelirlerini tahsil edemeyen bir alacaklı kesimin de varlı̆̆ ikramiyeli tahvillerin geri ödenmesine yönelik olan güveni sarsmaktaydı. İkramiye kazanan 99 bin tahvilden 4.118 tahvil sahibinin ikramiyelerini almaması, bu dönem ahşap evlerde yangınlarda kül olan tahvillerin varlığını akla getirmekteydi. Yangın gibi doğal afetlerde kaybolan tahviller olabileceği gibi tahvillerin bir kısmı da banka tarafından yapılan ödemelerde değer kaybetmekte, memurların dikkatsizliği yüzünden bir rakam unutulmakta ya da değiştirilmekteydi. 600.000 Frank ikramiye çıkan tahvil için 348.000 Frank ödeme yapılması gerekirken, tahvil değeri 110 Frank olarak kayıtlı olduğu için ödeme 110 Frank üzerinden yapılmaktayd. ${ }^{54}$ Rumeli demiryollarının finansmanı için 1870 ve 1872 yılında iki seri halinde çıkarılan ve kura ile ikramiye kazandıran tahviller, Avrupa finans çevresinde Lots Turcs olarak anılmış ve 1875 krizi sonrasında tahvil alacaklılarının pek azı ikramiye kazançlarından yararlanmıştı.

\section{Sonuç}

Ödemeleri 1875 Krizi sonrasında durdurulan ikramiyeli tahvillerin itfasında yaşanan sıkıntılar, Osmanlı borçlanmasının tahvil alacaklıları açısından yarattığı eşitsizlikleri incelemek açısından önemli ipuçları barındırmaktadır. İkramiyeli tahvillerin geri ödenmesinde uygulanan yöntemler ve uygulamaya konulmayan planlar, uluslararas1 alacaklı ülkelerin hükümet ve Düyun-u Umumiye İdaresi'nden beklentileri ve taleplerince şekillenmektedir. Osmanlı ekonomisinde artan kamu harcamalarını finanse etmek için yüksek faizlerle büyük miktarda borçlanılmasıyla, 19. yüzyıl boyunca borçlanmaya dayalı bir büyüme modeli oluşmaktaydı.

Osmanlı dış borçlanmasının en yoğun yaşandığı 1869-1875 yılları arasında Osmanlı tahvillerine olan talep, Avrupa'da yaşanan mali krizden dolayı düşmekteydi. 1870 ve 1872 yıllarında iki seri olarak ihraç edilen İkramiyeli tahviller, 1875'de dış borçlanmanın durdurulması ile askıya alınan ödemeler arasında yer almaktaydı. Düyun-u Umumiye İdaresi'nin kurulması ikramiyeli tahvillerin geri ödenmesini doğrudan etkileyen gelişmelerden biriydi. Düyun-u Umumiye İdaresi Osmanlı ekonomisinde uluslararası mali denetim sağlayan bir kurum olarak borçlanmanın finansmanını sağlayacak gelir kaynaklarının önemli bir kısmını yönetmekte ve yabancı doğrudan yatırımlarda etkili olmaktaydı. Dünya ekonomisinde ise ekonomik büyümeyi hızlandıran kapsayıcı kurumlar, kaynakları verimli ve etkin kullanma kapasitesine sahipti. Osmanlı vergi kaynaklarını yeni teknikler uygulayarak verimli hale getiren ve yetişmiş işgücü ile vergi tahsilatında etkinlik sağlayan Düyun-u Umumiye İdaresi, Osmanlı ekonomisinde borç yönetimi ile birlikte

53 Toprak, “Osmanlı İkramiyeli Devlet Borçları”,122.

54 Morawitz, Türkiye Maliyesi, 211. 
ekonomik gelişme düzeyini de doğrudan etkilemekteydi. Osmanlı tahvil alacaklılarının Osmanlı borçları üzerindeki denetimini sağlayan Düyun-u Umumiye İdaresi, faaliyetleri ve organizasyonu bakımından Avrupalı tahvil alacaklılarının ve dolayısıyla Avrupa devletlerinin kontrolü altındaydı. Kurum bu anlamda demiryolu imtiyazlarının dağıtılması gibi madencilik ve demiryolu alanındaki doğrudan yabancı yatırımları denetlemekte ve yönlendirmekteydi. Osmanlı ekonomisine yatırım yapan demiryolu ortaklıklarının yönetim kurulu üyelerinin Düyun-u Umumiye İdaresi'nde yer alması, İdare'nin firmaların kârlılıklarını güvence altına almasına yol açmakta ve Osmanlı ekonomisinde tam ve tek taraflı bir denetimin kurulmasını kolaylaştırmaktaydı.

Yabancı demiryolu yatırımları, kilometre garantisi nedeniyle hazineye oldukça ağır bir maliyet yüklemekle birlikte, ulaşım altyapısının kurulması nedeniyle vergi gelirlerinde beklenenin üzerinde bir artışa neden oldu. Kapsayıcı ekonomik kurumların gelir kaynakları üzerindeki verimlilik arttırıcı yatırımlarına örnek gösterilebilecek demiryolu yatırımları, Osmanlı ekonomisinin tarımsal meta üretimi ihracatına dayalı ekonomik yapısını desteklemekle birlikte, üretilen artığın paylaşımında sorunlara yol açmaktaydı. Tarımsal üretimin, sanayi sermayesi birikimine dönüşmeyip, ticaret ve diş borçlanma ilişkileri ile uluslararası sermayeye entegrasyonu, Osmanlı geç sanayileşmesinin nedenlerinden biridir. Osmanlı ekonomisinin Dünya ekonomisine entegrasyonunu hızlandıran demiryolu yatırımları hükümet açısından olduğu kadar, Avrupalı yatırımcılar açısından da kârlı bir faaliyet olarak görülmekteydi. Demiryolu yatırımcıları ile Düyun-u Umumiye İdaresi arasındaki işbirliği tahvil sahiplerinin alacaklarını tahsil etme yönündeki beklentisini karşılamaktaydı. Avrupa finans çevrelerinde Düyun-u Umumiye’ye duyulan güven, Rumeli demiryolu yatırımlarının finansmanı için çıkarılan İkramiyeli tahvillerin uluslararası finans merkezlerinde talep görmesine neden olmaktaydı. Bu durum Düyun-u Umumiye İdaresi'nin Osmanlı ekonomisindeki mali vesayetini arttırmaktaydı. Osmanlı devlet tahvilleri uluslararası piyasalardan talep görmekte, Osmanlı dış borçlanması finansal krizler ve spekülatif finansal işlemlere açık hale gelmekteydi.

Osmanlı borçlarının birleştirilmesi ve konversiyonunun gerçekleştirildiği 1890 yılında İkramiyeli tahvillerin faiz ve anapara ödemelerine kota ayrılmamış olması uluslararası tahvil alacaklıları komiteleri tarafından tepkiyle karşılandı. 1893 yılında İkramiyeli tahviller için hazırlanan ödeme planının uygulanmaması uluslararası yatırımcıların güvenini sarsıcı bir etki yarattı. İkramiyeli tahvillerin 1975 yılına kadar olan geri ödeme süresi, Osmanlı ekonomisi üzerindeki mali denetimin uzun vadede devam edeceği yönündeki yaklaşımı ortaya koymaktadır. Düyun-u Umumiye İdaresi’nin varlığının ortadan kalkması halinde bile tahvil sahiplerinin alacak haklarını kaybetmeyeceği, Muharrem Kararnamesi'nde güvence altına alınmaktaydı. Yabancı tahvil sahipleri alacak haklarını tahsis etme konusunda sendikalar aracılığıyla haklarını muhafaza etme yolunu seçmişti. Geri ödenmesi 1975 yılına kadar uzatılan ikramiyeli tahvillerin Rumeli Demiryolu'nun finansmanında bir fon oluşturmasına rağmen, binlerce tahvil sahibi hane için finansal getiriden bahsetmek olanaksızdır. İkramiye kazanan tahvil sahiplerinden ikramiye alamayanların sayısının artması ve kaybolan tahvillerin olması düşündürücüdür.

Neoliberal küreselleşme döneminde finansallaşmanın gelir dağılımına etkilerinden biri hanehalkının finans piyasasına erişiminin artması, finansal olarak içerilmesidir. 
Birinci Küreselleşme Evresi boyunca artan diş borçlanma talebi ile finans sermayenin uluslararasılaşma düzeyinde yaşanan artış günümüzdekine benzer bir finansal içerilmenin yaşandığına dair ipuçlarını barındırmaktadır. İkramiyeli tahviller örneğinde de görüldüğü üzere, toplumun farklı kesimleri devlet tahvilleri alarak borçlanma ilişkisine hızla çekilmektedir. Osmanlı ekonomisi, Birinci Küreselleşme Evresinde yaşanan ekonomik büyüme dalgasından olumlu yönde etkilenmekle birlikte ekonomik büyümenin dış borçlanmaya bağımlı yapısı Osmanlı tahvil alacaklılarının finansal içerilmesinde eşitsizlikler yaratmaktadır. Dış borçlanmaya dayalı ekonomik büyüme, toplumsal kesimler arasındaki eşitsizlikleri kalıcı hale getirmektedir. Osmanlı ekonomisinde ekonomik büyümenin gelir dağılımında yarattığı eşitsizlikler finansal içerilme ile birlikte artmaktadır. Galata Borsa'sında havaoyunları sonucunda servetini yitirenlerin sayısı, finans çevrelerinin devlet tahvillerinden elde ettikleri spekülatif kazançla birlikte hızla artmaktadır.

\section{Kaynakça}

Acemoğlu, Daron ve James A. Robinson. Ulusların Düşüşü: Güç, Zenginlik ve Yoksulluğun Kökenleri, çev. Faruk Rasim Velioğlu. İstanbul: Doğan Kitap, 34. Baskı, 2018.

Birdal, Murat. The Political Economy of Ottoman Public Debt Insolvency and European Financial Control in the Late Nineteenth Century. Newyork: Tauris Academic, 2010.

Blaisdell, Donald C. Osmanlı Imparatorluğu'nda Avrupa Mali Denetimi:

Düyunuumumiye. çev. Ali İhsan Dalgıç. İstanbul: Doğu-Batı yayınları, 1979.

Conte, Giampolo and Gaetano Sabatini. "The Ottoman External Debt and its Features under European Financial Control (1881-1914)". Journal of European Economic History 43, no.3 (2014): 69-96.

Eldem, Edhem. "Ottoman Financial Integration with Europe: Foreign Loans, the Ottoman Bank and the Ottoman Public Debt". European Review 13, no.3 (July 2005): 431-445.

Ergüder, Başak. Galata Hanları: Paranın Serüveni. İstanbul: SAV, 2011. Gürsoy, Bedri. "100. Yılında Düyun-u Umumiye İdaresi Üzerinde Bir Değerlendirme”. İstanbul Üniversitesi Iktisat Fakültesi Mecmuası 1-4 (Şükrü Baban'a Armağan), cilt:40 (1984): 17-59.

Heper, Metin. Türkiye'de Devlet Geleneği. Ankara: Doğu Batı, 1985. İnalc1k, Halil. "Turkey Between Europe and the Middle East, Perceptions". Journal of International Affairs 3, no.1 (March-May, 1998): 5-18.

Johnson, Alexander. The Gabriel Aubaret Archive of Ottoman Economic and Transportation History (Dasa Pahor). http://www.pahor.de January 29, 2019.

Karaman, K. Kivanç and Şevket Pamuk. "Ottoman State Finances in European Perspective, 1500- 1914. The Journal of Economic History 70, No. 3 (September 2010): 
593-629.

Kazgan, Gülten. Tanzimat'tan 21. Yüzyıla Türkiye Ekonomisi. İstanbul: İstanbul Bilgi Üniversitesi Yayınları, 2. Baskı, 2004.

Keyder, Çağlar. State and Class in Turkey: A Study in Capitalist Development. Newyork: Verso Books, 2003.

Morawitz, Charles. Türkiye Maliyesi. Ankara: Maliye Bakanlığı Tetkik Kurulu Yayını, 1978.

Özdemir, Biltekin. Osmanlı Devleti Dış Borçları. Ankara: Maliye Bakanlığı Strateji Geliştirme Başkanlığı, 2. Bask1, 2010.

Pamuk, Şevket. Osmanlı Imparatorluğu'nda Paranın Tarihi. İstanbul: Tarih Vakfi Yurt Yayınları, 1999.

Pamuk, Şevket. Osmanlı Ekonomisinde Bağımlılık ve Büyüme. İstanbul: Tarih Vakfı yayınları, 2005.

Pamuk, Şevket. "Seçici Kurumsal Değişim ve Osmanlı’nın Uzun Ömürlülüğü̈”. Toplumsal Tarih 134, no.1 (Şubat 2005): 34-42.

Tekeli, İlhan ve Selim İlkin. Cumhuriyetin Harcı: Modernitenin Altyapısı Oluşurken. İstanbul: İstanbul Bilgi Üniversitesi Yayınları, 2004.

Toprak, Zafer. “Osmanlı Devleti’nin Birinci Dünya Savaşı Finansmanı ve Para Politikası”. ODTÜ Gelişme Dergisi (Özel Sayı, 1979-1980): 205-238.

Toprak, Zafer. "Osmanlı İkramiyeli Devlet Borçları, Rumeli Demiryolları ve Duyunu Umumiye". Toplum ve Bilim Dergisi (Güz 81- Kış 82, 1981): 117-118.

Toprak, Zafer. "From Liberalism to Solidarism: The Ottoman Economic Mind in the Age of the Nation State (1820-1920)". In Studies in Ottoman Social and Economic Life, edited by. Raoul Motika, Christoph Herzog, Michael Ursinus, 171-190. Heidelberg: Heidelberger Orientverlag, 1999.

Toprak, Zafer. "Küreselleşme Evreleri ve Türkiye'de Finansal Yapının Evrimi". Küreselleşen İstanbul'da Ekonomi içinde, ed. Çağlar Keyder, 85-90. İstanbul: Osmanlı Bankası Arşiv ve Araştırma Merkezi, 2010.

Yeniay, İ. Hakkı. Yeni Osmanlı Borçları Tarihi. İstanbul: Ekin Yayınevi, 1964. 